\title{
Identifikasi Waste dengan Metode Waste Assessment Model dalam Penerapan Lean Manufacturing untuk Perbaikan Proses Produksi (Studi Kasus pada Proses Produksi Sarung Tangan)
}

\author{
Reza Alfiansyah dan Nani Kurniati \\ Departemen Teknik Industri, Fakultas Teknologi Industri, Institut Teknologi Sepuluh Nopember (ITS) \\ e-mail: nanikur@ie.its.ac.id
}

\begin{abstract}
Abstrak-PT. X merupakan perusahaan yang bergerak pada bidang manufaktur sarung tangan rajut. Sarung tangan rajut merupakan sarung tangan yang digunakan sebagai Alat Pelindung Diri (APD) pada industri perkebunan, perikanan maupun kegiatan konstruksi. Dalam proses produksinya, masih ditemukan berbagai indikasi waste yang menyebabkan menurunnya efisensi dan efektivitas proses produksi. Salah satu permasalahan terbesar adalah defect dengan presentase defect BS diatas $4.6 \%$ dan defect afkir sebesar $1.813 \%$. Selain itu, ditemukan berbagai indikasi waste terkait waste waiting, transportation dan berbagai waste lainnya. Adanya berbagai waste tersebut menyebabkan munculnya potential profit loss yang hilang bagi perusahaan. Penelitian ini bertujuan untuk mengeliminasi waste pada proses produksi sarung tangan di PT. $\mathrm{X}$ dengan implementasi metode lean manufacturing. Langkah awal penelitian dilakukan dengan identifikasi proses produksi dan waste menggunakan Operation Process Chart (OPC), Value Stream Mapping (VSM) dan Waste Assessment Model (WAM). Berdasarkan WAM, diketahui 3 waste kritis yaitu defect, waiting dan transportation. Selanjutnya dilakukan analisis akar masalah dengan Root Cause Analysis (RCA) 5Why's dan mencari nilai risiko kegagalan menggunakan Failure Mode and Effect Analysis (FMEA). FMEA dikategorikan kritis ketika nilai RPN $\geq 240$ untuk kemudian dilakukan analisis perancangan rekomendasi perbaikan. Terdapat 3 alternatif perbaikan yaitu pengurangan defect proses produksi, perbaikan sistem serta perbaikan sistem manajemen dan produksi. Pemilihan alternatif dilakukan dengan menggunakan value management. Berdasarkan value management, didapatkan kombinasi alternatif perbaikan terbaik adalah alternatif 1 dan 2 .
\end{abstract}

Kata Kunci-5 Why's, Failure Mode and Effect Analysis (FMEA), Lean manufacturing, Value management, Value Stream Mapping (VSM), Waste Assessment Model (WAM).

\section{PENDAHULUAN}

$\mathrm{P}$ T. X merupakan perusahaan yang memproduksi sarung tangan rajut yang didirikan pada tahun 1995 dan berlokasi di Kawasan Industri Driyorejo, Gresik, Jawa Timur. Sarung tangan rajut merupakan sarung tangan safety sekali pakai yang digunakan pada berbagai industri seperti pertanian, perkebunan maupun pada kegiatan konstruksi bangunan. Terdapat 4 proses utama dalam produksi sarung tangan, yaitu proses rajut (knitting), obras, dotting dan packaging. PT. X memiliki beberapa variasi produk berdasarkan tipe benang (benang 3,4,5,6,7, bleach) dan tipe sarung tangan (biasa dan dot). Pada gambar 1.2 berikut menunjukkan persentase penjualan sarung tangan berdasarkan jenis produk pada bulan Juni 2017- Agustus 2017.

\section{Persentase Penjualan Produk (Juni 2017-Agustus 2017)}

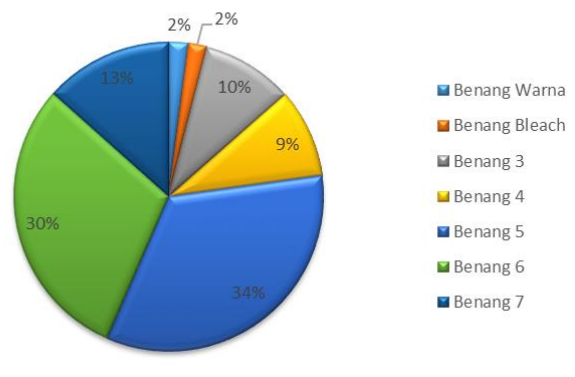

Gambar 1. Persentase Penjualan Produk Sarung Tangan di PT. X bulan Juni 2017-Agustus 2017

Proses produksi sarung tangan harus berjalan secara efisien agar dapat menekan cost produksi sehingga mampu menghasilkan harga dan kualitas yang dapat bersaing. Namun begitu, masih banyak ditemukan berbagai indikator pemborosan (waste) yang terjadi pada proses produksi sarung tangan di PT. X.

Salah satu indikasi waste yang paling besar adalah defect. Perusahaan membagi produk kedalam 4 kategori, yaitu accept, rework, BS dan reject (afkir). Produk rework adalah produk dengan rajutan tidak sempurna yang mengakibatkan munculnya lubang sehingga harus melalui proses rework berupa tisik. Produk BS merupakan sarung tangan dengan panjang yang tidak sesuai standar dan jari sarung tangan menempel. Produk tersebut akan dijual kepada konsumen namun dengan harga yang lebih rendah. Berikut merupakan data produk BS pada periode Juni 2017-Agustus 2017: 
Tabel 1.

Persentase Produk BS

\begin{tabular}{llll}
\hline \hline & Juni-17 & Juli-17 & Agustus-17 \\
\hline Produksi & 43000 & 73850 & 76300 \\
Defect & 2000 & 8550 & 3550 \\
Persentase Defect & $4.6512 \%$ & $11.5775 \%$ & $4.6527 \%$ \\
\hline \hline
\end{tabular}

Berdasarkan data tersebut, diketahui bahwa jumlah produk BS masih cukup tinggi dan melebihi target produk BS yaitu sebesar $4 \%$. Berdasarkan data yang didapat, produk BS tersebut akan menurunkan harga jual rata-rata sebesar 45,65\%. Adanya penurunan harga tersebut akan mengakibatkan potential loss yang besar bagi perusahaan.

Produk jenis keempat yaitu afkir berupa lubang besar pada sarung tangan serta dotting yang tidak sesuai. Berdasarkan data pada bulan Oktober 2017, diketahui bahwa tingkat produk reject masih sebesar 1,813\% dan menyebabkan produk tersebut tidak dapat dijual ke konsumen dan menimbulkan potential loss yang besar bagi perusahaan.

Indikasi waste lainnya adalah waste waiting pada proses breakdown mesin. Mesin rajut merupakan mesin yang sering mengalami breakdown, sedangkan mesin dotting merupakan mesin dengan frekuensi breakdown lebih rendah namun membutuhkan waktu penanganan perbaikan yang lebih lama. Kerusakan tersebut mengakibatkan terganggunya aliran proses produksi sarung tangan di PT.X.

Indikasi waste lainnya yang muncul adalah terkait transportasi dimana masih terdapat permasalahan pada routing yang tidak searah karena adanya permasalahan layout. Selain itu, keterbatasan material handling juga menyebabkan terjadinya antrian proses produksi.

Berdasarkan permasalahan yang telah dipaparkan, terdapat berbagai indikasi waste yang menyebabkan potential loss perusahaan. Permasalahan tersebut dapat diminimalisir dengan menggunakan metode lean manufacturing. Lean manufacturing adalah filosofi manajemen proses yang berasal dari Toyota Production System (TPS), yang terkenal karena menitikberatkan pada peniadaan seven waste dengan tujuan peningkatan kepuasan konsumen secara keseluruhan [1]. Langkah yang dilakukan adalah dengan mengidentifikasi seluruh waste serta akar permasalahannya untuk kemudian dilakukan perancangan perbaikan pada proses produksi sarung tangan.

Rumusan masalah dalam penelitian ini adalah bagaimana cara mereduksi waste yang timbul akibat pemborosan proses produksi sarung tangan pada PT. X melalui pendekatan lean manufacturing. Tujuan dari penelitian ini adalah untuk memberikan deskripsi proses produksi eksisting sarung tangan, mengidentifikasi waste kritis pada proses produksi sarung tangan, mengidentifikasi akar permasalahan waste kritis serta menghasilkan rekomendasi perbaikan sarung tangan di PT. X.

\section{METODOLOGI PENELITIAN}

\section{A. Tahap Identifikasi Awal}

Pada tahap ini akan dijelaskan tahapan awal yang dilakukan dalam penelitian berupa identifikasi masalah, studi literatur, studi lapangan, perumusan masalah serta penentuan tujuan penelitian

\section{B. Tahap Pengumpulan dan Pengolahan Data}

Pada tahap ini dilakukan pengumpulan data primer dan sekunder yang akan digunakan dalam penelitian. Data primer merupakan data yang didapat secara langsung melalui pengamatan dan wawancara. Data tersebut berupa waktu proses, kuesioner identifikasi waste, serta kuesioner input FMEA. Data sekunder berupa data yang didapat berdasarkan database/laporan perusahaan berupa profil perusahaan, laporan penjualan, serta kapasitas mesin produksi.

Selanjutnya dilakukan pengolahan data berupa pemetaan proses produksi dengan Operation Process Chart (OPC) dan Value Stream Mapping (VSM), identifikasi waste serta waste kritis dengan metode Waste Assessment Model (WAM) serta identifikasi biaya kerugian (potential loss) akibat waste.

\section{Analisis dan Interpretasi Data}

Pada tahap ini akan dilakukan analisis terkait pengolahan data pada tahap sebelumnya. Analisis dilakukan terhadap pemetaan proses produksi berdasarkan OPC dan VSM, serta analisis keterkaitan antar waste dan analisis waste kritis berdasarkan metode WAM. Selain itu, dilakukan analisis terhadap akar permasalahan penyebab waste kritis dengan Root Cause Analysis 5Why's. Selanjutnya akan dilakukan penilaian terhadap risiko akar penyebab waste tersebut dengan menggunakan Failure Mode and Effect Analysis (FMEA).

\section{Perancangan Rekomendasi Perbaikan}

Pada tahap ini akan dilakukan perancangan rekomendasi perbaikan berdasarkan RCA dan FMEA. Kemudian akan dilakukan penyusunan kombinasi alternatif perbaikan. Selanjutnya akan dilakukan pemilihan alternatif dengan menggunakan value management untuk menentukan alternatif perbaikan terbaik berdasarkan cost yang dikeluarkan dan value yang didapat perusahaan.

\section{E. Kesimpulan dan Saran}

Pada tahap ini akan dilakukan penarikan kesimpulan dan pemberian saran terhadap perusahaan dan penelitian selanjutnya.

\section{PENGUMPULAN DAN PENGOLAHAN DATA}

\section{A. Gambaran Umum Perusahaan}

PT. X merupakan salah satu industri yang bergerak pada bidang produksi sarung tangan rajut yang telah didirikan sejak tahun 1995 dan berlokasi di Kawasan Industri Driyorejo, Gresik, Jawa Timur. Perusahaan menghasilkan berbagai sarung tangan rajut berdasarkan tipe benang (benang 3,4,5,6,7, bleach) dan tipe sarung tangan (biasa dan dot). 


\section{B. Identifikasi Proses Produksi}

Proses produksi sarung tangan terdiri dari 4 proses utama yaitu rajut, obras, dotting dan packaging. Proses packaging sendiri terdiri dari 3 subproses yaitu satter, packaging dan memasukkan dalam karung. Penggambaran proses produksi dilakukan dengan menggunakan OPC dan VSM. Dengan menggunakan OPC, dapat dilihat semua urutan proses kerja yang dialami oleh suatu benda kerja atau input dari saat mulai masuk ke lokasi kegiatan kemudian menggambarkan semua langkah aktivitas yang dialaminya seperti: transportasi, operasi kerja, inspeksi, menunggu (delay) dan menyimpan, sampai akhirnya menjadi suatu produk akhir [2]. Berikut merupakan penggambaran OPC proses produksi setiap 1 lusin sarung tangan:

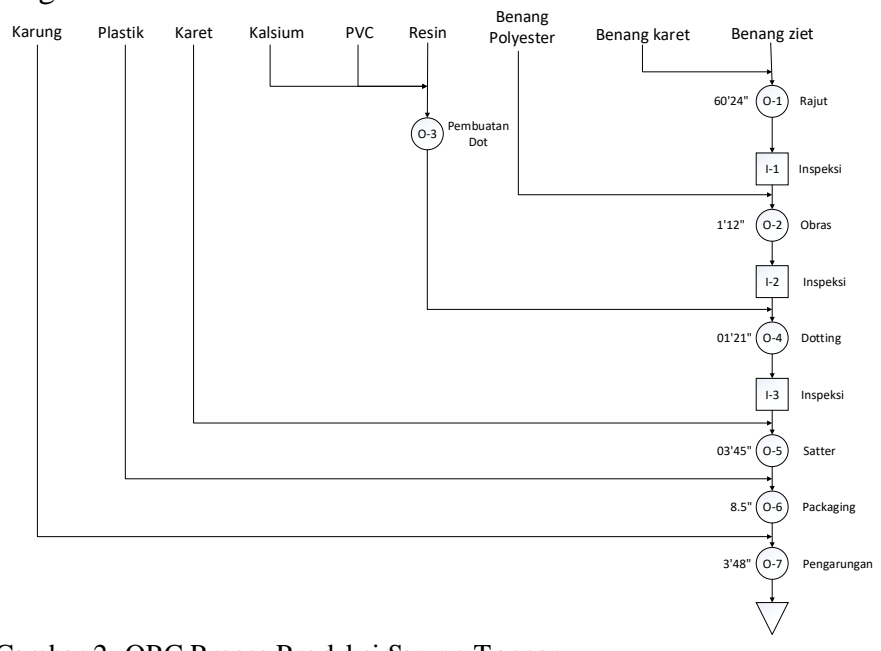

Gambar 2. OPC Proses Produksi Sarung Tangan.

Value Stream Mapping merupakan tools yang digunakan untuk menggambarkan aliran informasi dan aliran material sesuai kondisi eksisting perusahaan. VSM dapat menyajikan suatu titik balik yang optimal bagi setiap perusahaan yang ingin menjadi lean [3]. Penggambaran VSM dilakukan berdasarkan pembuatan satu karung (50 lusin) sarung tangan. Berikut merupakan VSM pada proses produksi sarung tangan:
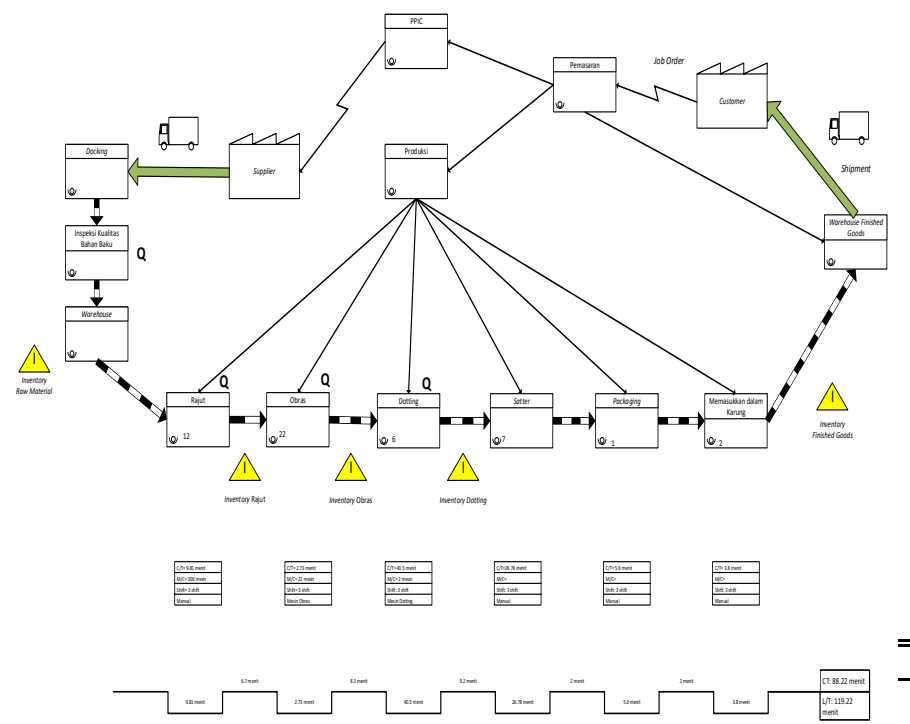

Gambar 3. VSM Proses Produksi Sarung Tangan
Berdasarkan penggambaran VSM tersebut, dapat diketahui waktu siklus sebesar 88.2 menit dan lead time sebesar 119.22 menit sehingga menghasilkan efisiensi proses produksi sebesar $73.99 \%$.

\section{Identifikasi Waste}

Teori Toyota Production System mengidentifikasi terdapat 7 pemborosan [4]. Berdasarkan pengamatan dan brainstorming dengan pihak perusahaan, dapat diketahui waste proses produksi sebagai berikut:

a) Overproduction

Perusahaan melakukan forecast kebutuhan berdasarkan data historis. Terdapat overproduction pada proses produksi untuk mengatasi fluktuasi demand, sehingga tidak hingga menyebabkan waste.

b) Waiting

Terdapat waste pada waktu tunggu perbaikan mesin breakdown serta menunggu proses rework.

c) Transportation

Proses produksi sarung tangan terjadi pada 3 lantai, yaitu lantai 1 untuk gudang raw material dan finished goods, lantai 2 untuk proses rajut, obras dan packaging, serta lantai 3 digunakan untuk proses dotting dan rajut. Terdapat layouting yang tidak searah serta kurangnya fasilitas material handling. d) Excess Process

Terdapat beberapa kesalahan entry data oleh operator, namun tidak signifikan.

e) Inventory

Terdapat penumpukan inventory namun untuk mengatasi fluktuasi demand dan lead time.

\section{f) Motion}

Terdapat penataan barang yang tidak rapi, aisle yang sempit serta kemampuan operator yang berbeda-beda.

\section{g) Defect}

Terdapat 5 jenis defect yaitu rajutan tidak sempurna, jari sarung tangan menempel, panjang tak sesuai standar, lubang besar serta dotting tidak sesuai spesifikasi.

\section{Indetifikasi Waste Kritis dengan WAM}

Identifikasi waste kritis dilakukan dengan menggunakan Waste Assessment Model (WAM). WAM merupakan suatu model yang dikembangkan untuk menyederhanakan pencarian dari permasalahan waste untuk mengidentifikasi dalam mengeliminasi waste [5]. Metode WAM merupakan metode yang mampu menunjukkan keterkaitan antar waste serta menunjukkan peringkat waste kritis. Selain itu, metode ini mampu meminimalisir subjektivitas expert. Terdapat tiga langkah dalam WAM, yaitu Seven Waste Relationship (SWR), Waste Relationship Matrix (WRM) serta Waste Assessment Questionnaire (WAQ). Berdasarkan SWR dan WRM, dapat diketahui keterkaitan antar waste yaitu sebagai berikut:

Tabel 2.

Hasil Perhitungan WRM

\begin{tabular}{crrrrrrrrr}
\hline \hline F/T & \multicolumn{1}{l}{ O } & \multicolumn{1}{c}{ I } & \multicolumn{1}{c}{ D } & M & T & P & W & Skor & \% \\
\hline O & 10 & 2 & 6 & 2 & 4 & 0 & 2 & 26 & 12.75 \\
I & 4 & 10 & 2 & 2 & 4 & 0 & 0 & 22 & 10.78 \\
D & 4 & 4 & 10 & 6 & 6 & 0 & 6 & 36 & 17.65
\end{tabular}




\begin{tabular}{crrrrrrrrrr}
$\mathbf{M}$ & 0 & 2 & 10 & 10 & 0 & 4 & 4 & 30 & 14.71 & 3. Transportation \\
$\mathbf{T}$ & 2 & 4 & 2 & 4 & 10 & 0 & 8 & 30 & 14.71 & Terdapat beberapa permasalahan terkait transportation \\
$\mathbf{P}$ & 2 & 2 & 10 & 2 & 0 & 10 & 8 & 34 & 16.67 & Tan \\
$\mathbf{W}$ & 2 & 4 & 10 & 0 & 0 & 0 & 10 & 26 & 12.75 yang menghambat jalannya proses produksi perusahaan. \\
Skor & 24 & 28 & 50 & 26 & 24 & 14 & 38 & 204 & 100.00 & Namun, potential loss tidak dapat dihitung karena tidak \\
$\%$ & 11.76 & 13.73 & 24.51 & 12.75 & 11.76 & 6.86 & 18.63 & 100.00 & & terdapat data perbandingan waktu transportation optimal. \\
\hline \hline
\end{tabular}

Berdasarkan tabel tersebut, dapat diketahui waste "from" terbesar adalah defect (17,65\%) dan process $(16,67 \%)$. Sedangkan waste "to" terbesar adalah defect $(24,51 \%)$ dan waiting $(18,63 \%)$. Berdasarkan hasil tersebut, kemudian dilakukan metode WAQ dan menghasilkan waste kritis sebagai berikut:

Tabel 3.

Hasil Perhitungan WAM

\begin{tabular}{llllllll}
\hline \hline & $\mathrm{O}$ & $\mathrm{I}$ & $\mathrm{D}$ & $\mathrm{M}$ & $\mathrm{T}$ & $\mathrm{P}$ & $\mathrm{W}$ \\
\hline $\begin{array}{l}\text { Skor } \\
(\mathrm{Yj})\end{array}$ & 0.35 & 0.34 & 0.30 & 0.25 & 0.32 & 0.21 & 0.26 \\
$\mathrm{Pj}$ & 149.9 & 148.0 & 432.5 & 187.4 & 173.0 & 114.3 & 237.4 \\
Factor & 4 & 2 & 3 & 3 & 1 & 8 & 1 \\
$\mathrm{Yj}$ & 53.00 & 49.60 & 129.0 & 46.71 & 54.86 & 24.02 & 61.64 \\
Final & & & 8 & & & & \\
Persen & 12.65 & 11.84 & 30.81 & 11.15 & 13.10 & 5.73 & 14.71 \\
tase & $\%$ & $\%$ & $\%$ & $\%$ & $\%$ & $\%$ & $\%$ \\
& 4 & 5 & 1 & 6 & 3 & 7 & 2 \\
\hline \hline
\end{tabular}

Berdasarkan WAM, diketahui bahwa waste kritis tertinggi adalah defect $(30,81 \%)$, waiting $(14,71 \%)$ dan transportation $(13,10 \%)$.

\section{E. Identifikasi Biaya Kerugian Waste Kritis}

\section{Defect}

Biaya Potential loss akibat defect diakibatkan oleh penurunan harga jual produk BS, kerugian akibat produk afkir yang tidak dapat dijual serta potential loss akibat biaya pekerja rework.

Tabel 4.

Biaya Kerugian Akibat Waste Defect

\begin{tabular}{lrr}
\hline \hline Potential loss & \multicolumn{2}{l}{ Jumlah } \\
\hline Produk BS (Sortir) & $\mathrm{Rp}$ & $82,250,328$ \\
Produk Afkir & $\mathrm{Rp}$ & $61,369,311$ \\
Tenaga Kerja Rework & $\mathrm{Rp}$ & $21,499,872$ \\
Total & $\mathrm{Rp}$ & $165,119,511$ \\
\hline \hline
\end{tabular}

\section{Waiting}

Biaya kerugian akibat waiting terjadi karena adanya loss production akibat pergantian jarum dan breakdown mesin. Pergantian jarum terjadi sebesar 60 kali dalam sehari, sedangkan kerusakan mesin knitting 15,5 mesin/ bulan serta breakdown mesin dotting sebesar 1.7 mesin/bulan.

Tabel 5.

Biaya Kerugian Akibat Waste Waiting

\begin{tabular}{ll}
\hline \hline Potential loss & Jumlah \\
\hline Pergantian Jarum & Rp 2,869,384 \\
Mesin Knitting & Rp 117,288 \\
Mesin Dotting & Rp 4,681,263 \\
Total & Rp 16,913,173 \\
\hline \hline
\end{tabular}

\section{ANALISIS DAN INTERPRET ASI DAT A}

\section{A. Analisis Proses Produksi}

OPC digunakan untuk mengetahui alur proses produksi serta waktu yang terjadi untuk setiap proses. Berdasarkan OPC dapat diketahui jika proses rajut merupakan proses dengan waktu terlama yaitu 1 jam 24 detik. Oleh karena itu, dibutuhkan investasi jumlah mesin yang banyak untuk proses tersebut. Selain itu, proses dotting dan obras memiliki waktu yang hampir sama namun jumlah mesin/operator berbeda jauh. Hal tersebut terjadi karena tidak semua porses sarung tangan melalui proses dotting, sehingga terdapat perbedaan yang signifikan antara jumlah mesin obras dan mesin dotting.

VSM digunakan untuk mengetahui aliran informasi dan fisik proses produksi, serta mengetahui waktu siklus produksi. Berdasarkan VSM, dapat diketahui waktu siklus terlama terjadi pada proses satter sehingga dapat menyebabkan bottleneck pada proses tersebut. Proses satter dilakukan secara manual oleh 7 orang operator sehingga skill dari setiap operator sangat mempengaruhi waktu proses tersebut. Berdasarkan VSM juga dapat diketahui masih terjadi waste waiting, transportation dan inventory pada proses produksi. Waktu siklus produksi sebesar 88.2 menit dengan lead time 119.22 menit atau efisiensi proses sebesar 73,99\%.

\section{B. Analisis Waste Kritis Berdasarkan WAM}

Berdasarkan WAM, dapat diketahui keterkaitan antar waste pada proses produksi. Berdasarkan SWR dan WRM, diketahui bahwa waste "from" terbesar adalah from defect dan from process. Hal tersebut menunjukkan bahwa kedua waste tersebut menyebabkan munculnya waste lain. Contohnya adalah munculnya waste defect akan menyebabkan meningkatnya intensitas transportation serta motion karena terdapat proses rework akibat waste defect. Selain itu waste process karena ketidaksesuaian proses pada mesin dapat menyebabkan munculnya defect dan berbagai waste lainnya. Sedangkan waste "to" terbesar adalah to defect dan to waiting. Contohnya adalah adanya waste motion berupa skill operator yang berbada dapat menyebabkan timbulnya defect. Contoh lain adalah waste transportation karena kurangnya material handling akan menyebabkan waktu tunggu proses produksi.

Pada tahap WAQ, dilakukan input berdasarkan perhitungan WRM. Diketahui waste kritis pada perusahaan adalah defect $(30,81 \%)$, waiting $(14,71 \%)$ serta transportation $(13,10 \%)$.

\section{Analisis Waste Kritis dengan RCA dan FMEA}

Berdasarkan waste kritis yang telah diidentifikasi, kemudian dilakukan analisis akar permasalahan dengan menggunakan 5 Why's. Metode 5 Why's digunakan dengan bertanya mengapa beberapa kali sehingga tindakan yang sesuai dengan akar 
penyebab masalah yang ditemukan untuk menghilangkan masalah [6]. Akar permasalahan didapat melalui pengamatan serta brainstorming dengan pihak expert perusahaan.

Pada waste defect, terdapat 5 sub waste yaitu rajutan tidak sempurna, panjang jari tidak sesuai spesifikasi, lubang besar, jahitan menempel serta dotting yang tidak sesuai. Akar permasalahan tersebut timbul akibat adanya pergeseran plat hook akibat getaran, bahan baku yang tersimpan di tempat yang lembap, terjadi pergeseran dial, rantai yang telah lama digunakan, kualitas brush yang buruk, operator kurang fokus dalam bekerja, tidak dilakukan pembersihan screen serta tidak terdapat prosedur pergantian karet sablon.

Pada waste waiting, terdapat 2 sub waste yaitu menunggu perbaikan mesin serta menunggu perbaikan produk rework. Akar permasalahan waste tersebut karena tidak adanya penjadwalan preventive maintenance, mesin produksi merupakan mesin lama, tidak terdapat penjadwalan khusus bagi teknisi serta tidak ada SOP klasifikasi dan penanganan produk defect.

Pada waste transportation terdapat 3 sub waste, yaitu pengangkutan raw material yang lama, pengangkutan dari dan menuju area dotting serta lamanya waktu transportasi keseluruhan. Akar penyebab waste tersebut adalah keterbatasan jumlah material handling, material handling dilakukan manual, penataan layout yang kurang baik serta tidak adanya penerapan 5S.

Berdasarkan akar permasalahan tiap waste kritis tersebut, kemudian dilakukan analisis menggunakan FMEA untuk menulai severity, occurance serta detection dari setiap akar penyebab permasalahan tersebut. FMEA bertujuan untuk mengidentifikasi dan memahami potensi penyebab dan efek suatu kegagalan, menilai risiko kegagalan dan melaksanakan tindakan korektif untuk mengatasi permasalahan [7].

\section{PERANCANGAN REKOMENDASI PERBAIKAN}

\section{A. AlternatifRekomendasi Perbaikan}

Berdasarkan analisis FMEA, dapat diketahui risiko terbesar terjadinya waste pada proses produksi. Kemudian dilakukan penanganan terhadap akar penyebab waste dengan nilai Risk Priority Number $(\mathrm{RPN}) \geq 240$. Pada tabel 5.1 berikut merupakan penanganan berdaskan nilai RPN pada penyebab waste.

Tabel 6.

Usulan Rekomendasi Perbaikan

\begin{tabular}{clcl}
\hline \hline Waste & \multicolumn{1}{c}{ Subwaste } & RPN & \multicolumn{1}{c}{$\begin{array}{c}\text { Langkah } \\
\text { Perbaikan }\end{array}$} \\
\hline \multirow{5}{*}{ Defect } & $\begin{array}{l}\text { Screen sablon tertutup } \\
\text { cairan sablon }\end{array}$ & 200 & \\
\cline { 2 - 3 } & $\begin{array}{l}\text { Twist bahan baku benang } \\
\text { memiliki kualitas yang } \\
\text { buruk }\end{array}$ & 270 & $\begin{array}{l}\text { Perbaikan kualitas } \\
\text { bahan baku }\end{array}$ \\
\cline { 2 - 4 } & $\begin{array}{l}\text { Terdapat jarum yang } \\
\text { patah saat proses } \\
\text { produksi berlangsung }\end{array}$ & 300 & $\begin{array}{l}\text { Perbaikan desain } \\
\text { Knitting }\end{array}$ \\
\cline { 2 - 4 } & $\begin{array}{l}\text { Operator kurang fokus } \\
\text { dalam memasukkan } \\
\text { sarung tangan ke mesin }\end{array}$ & 400 & $\begin{array}{l}\text { Perbaikan sistem } \\
\text { manajemen } \\
\text { produksi }\end{array}$ \\
\hline \hline
\end{tabular}

\begin{tabular}{|c|c|c|c|}
\hline \multirow{4}{*}{ Waiting } & $\begin{array}{l}\text { Tidak adanya } \\
\text { penjadwalan preventive } \\
\text { maintenance untuk } \\
\text { berbagai mesin }\end{array}$ & 245 & \multirow{2}{*}{$\begin{array}{l}\text { Pembuatan kartu } \\
\text { dan form } \\
\text { maintenance }\end{array}$} \\
\hline & $\begin{array}{l}\text { Tidak adanya } \\
\text { penjadwalan preventive } \\
\text { maintenance pada mesin } \\
\text { dotting }\end{array}$ & 280 & \\
\hline & $\begin{array}{l}\text { Penjadwalan bagi teknisi } \\
\text { hanya dilakukan pada } \\
\text { waktu tertentu }\end{array}$ & 400 & $\begin{array}{l}\text { Penjadwalan } \\
\text { teknisi untuk } \\
\text { maintenance } \\
\text { mesin }\end{array}$ \\
\hline & $\begin{array}{l}\text { Tidak adanya SOP } \\
\text { klasifikasi dan } \\
\text { penanganan produk } \\
\text { cacat }\end{array}$ & 350 & $\begin{array}{l}\text { Pembuatan SOP } \\
\text { klasifikasi dan } \\
\text { penanganan } \\
\text { produk cacat }\end{array}$ \\
\hline \multirow{3}{*}{ Transportation } & $\begin{array}{l}\text { Tidak ada penerapan } \\
\text { aturan maupun } \\
\text { penerapan } 5 \mathrm{~S} \text { pada } \\
\text { proses produksi }\end{array}$ & 300 & $\begin{array}{l}\text { Penerapan } 5 \mathrm{~S} \text { pada } \\
\text { perusahaan }\end{array}$ \\
\hline & $\begin{array}{l}\text { Fasilitas pengangkutan } \\
\text { atau hoist lain untuk } \\
\text { menaikkan raw material } \\
\text { ke lantai atas yang } \\
\text { minim }\end{array}$ & 240 & \multirow[t]{2}{*}{$\begin{array}{l}\text { Perbaikan fasilitas } \\
\text { material handling } \\
\text { optimal }\end{array}$} \\
\hline & $\begin{array}{l}\text { Kapasitas material } \\
\text { handling terbatas }\end{array}$ & 240 & \\
\hline
\end{tabular}

Kemudian, berdasarkan rancangan perbaikan tersebut dilakukan klasifikasi dan pembuatan alternatif perbaikan pada tabel 5.2.

Tabel 7.

Klasifikasi Alternatif Perbaikan

\begin{tabular}{|c|c|c|}
\hline $\mathrm{No}$ & Alternatif Perbaikan & Langkah Perbaikan \\
\hline 1 & $\begin{array}{l}\text { Pengurangan defect proses } \\
\text { produksi }\end{array}$ & $\begin{array}{l}\text { Perbaikan kualitas bahan baku } \\
\text { Perbaikan desain hook pada mesin } \\
\text { knitting }\end{array}$ \\
\hline 2 & $\begin{array}{l}\text { Perbaikan sistem } \\
\text { maintenance }\end{array}$ & $\begin{array}{l}\text { Pembuatan kartu dan form } \\
\text { maintenance } \\
\text { Penjadwalan teknisi untuk } \\
\text { maintenance mesin }\end{array}$ \\
\hline 3 & $\begin{array}{l}\text { Perbaikan sistem } \\
\text { manajemen dan produksi }\end{array}$ & $\begin{array}{l}\text { Pembuatan SOP klasifikasi dan } \\
\text { penanganan produk cacat } \\
\text { Penerapan 5S pada perusahaan } \\
\text { Perbaikan fasilitas material } \\
\text { handling optimal }\end{array}$ \\
\hline
\end{tabular}

\section{B. Pemilihan Alternatif Berdasarkan Value management}

Berdasarkan perancangan alternatif perbaikan yang telah dilakukan, kemudian dilakukan kombinasi alternatif perbaikan yang diusulkan. Perhitungan dilakukan dengan menggunakan metode value management. Value management merupakan sebuah teknik dengan menggunakan pendekatan sistematis untuk mencari keseimbangan fungsi terbaik antara biaya, keandalan, dan kinerja sebuah proyek [8]. Berikut merupakan rumus yang digunakan dalam metode value management.

1. Mencari Nilai Cost

$$
C^{\prime} n=\frac{P n}{P o} \times C o
$$


Dimana

C'n $=$ Cost alternatif ke-n

Co = Cost awal

$\mathrm{Pn}=$ Performansi alternatif ke-n

Po = Performansi awal

2. Mencari nilai Value

$$
V n=\frac{C^{\prime} n}{C n}
$$

Dimana

$\mathrm{Vn}=$ Value alternatif ke-n

$\mathrm{Vo}=$ Value kondisi eksisting

$\mathrm{Cn}=$ Cost alternatif ke-n

C'n = Besaran nilai rupiah untuk performansi

Selanjutnya ditentukan kriteria alternatif perbaikan yaitu persentase produk accept, reduksi lead time serta output produksi. Kemudian, dilakukan pembobotan dengan menggunakan Analytical Hierarcy Process (AHP) sehingga menghasilkan bobot pada tabel 5.3.

Tabel 8.

Hasil Pembobotan AHP

\begin{tabular}{lll}
\hline \hline Simbol & Kriteria Pemilihan Alternatif & Bobot \\
\hline K1 & Persentase Produk Accept & 0.594 \\
K2 & Reduksi Lead time & 0.249 \\
K3 & Output Produksi & 0.157 \\
\hline \hline
\end{tabular}

Kemudian dilakukan perhitungan cost dengan komponen biaya berupa biaya investasi, biaya tenaga kerja serta biaya energi. Langkah selanjutnya dilakukan pembagian kuesioner kepada expert perusahaan untuk penilaian terhadap kombinasi perbaikan berdasarkan kriteria perbaikan. Hal tersebut bertujuan untuk mengetahui besarnya value yang akan didapat berdasarkan penerapan rekomendasi perbaikan. Pada tabel 5.4 berikut merupakan hasil perhitungan value management.

Tabel 9.

Hasil Perhitungan Value Management

\begin{tabular}{|c|c|c|c|c|c|c|c|}
\hline \multirow{2}{*}{ Alt } & \multicolumn{3}{|c|}{ Bobot } & \multirow{2}{*}{$\begin{array}{l}\text { Per- } \\
\text { form }\end{array}$} & \multirow{2}{*}{ Cost } & \multirow{2}{*}{ C'n } & \multirow{2}{*}{ Value } \\
\hline & $\mathrm{K} 1$ & $\mathrm{~K} 2$ & K3 & & & & \\
\hline 0 & 6 & 7 & 7 & 6.406 & Rp256,591,888 & Rp256,591,888 & 1.000 \\
\hline 1 & 8 & 7 & 7 & 7.594 & Rp257,088,666 & Rp304,177,146 & 1.183 \\
\hline 2 & 7 & 8 & 8 & 7.406 & Rp256,931,088 & Rp296,646,819 & 1.155 \\
\hline 3 & 7 & 8 & 7 & 7.249 & Rp257,314,818 & Rp290,358,195 & 1.128 \\
\hline 1,2 & 9 & 8 & 8 & 8.594 & Rp257,427,866 & Rp344,232,077 & 1.337 \\
\hline 1,3 & 9 & 8 & 7 & 8.437 & $\operatorname{Rp} 257,811,596$ & Rp337,943,453 & 1.311 \\
\hline 2,3 & 8 & 8 & 8 & 8 & $\operatorname{Rp} 257,654,018$ & Rp320,439,448 & 1.244 \\
\hline $1,2,3$ & 9 & 8 & 8 & 8.594 & Rp258,150,796 & Rp344,232,077 & 1.333 \\
\hline
\end{tabular}

Berdasarkan value management, dapat diketahui bahwa kombinasi alternatif perbaikan $1 \& 2$ menghasilkan value paling besar bagi perusahaan.

\section{KESIMPULAN DAN SARAN}

\section{A. Kesimpulan}

Kesimpulan yang dapat diambil dari penelitian ini adalah:
1. Proses produksi sarung tangan rajut terdiri dari 4 tahapan utama yaitu proses rajut (knitting), obras, dotting dan packaging yang terdiri dari proses satter, pengemasan dan memasukkan dalam karung. Proses produksi sarung tangan rajut memiliki cycle time 88.2 menit dan lead time 119.22 menit dengan efisiensi 73,99\%.

2. Berdasarkan WAM, diketahui waste "from" terbesar adalah defect dan process sedangkan waste "to" terbesar adalah defect dan waiting. Waste kritis pada perusahaan adalah defect (30,81\%), waiting (14,71\%) serta transportation $(13,10 \%)$.

3. Berdasarkan RCA dan FMEA, kemudian ditentukan alternatif perbaikan berdas arkan nilai $\mathrm{RPN} \geq 240$. Terdapat 3 alternatif perbaikan yaitu pengurangan defect proses, perbaikan sistem maintenance dan perbaikan sistem manajemen.

4. Berdarkan value management, dilakukan perhitungan value yang didapat dari perbaikan terhadap cost yang dikeluarkan. Dapat diketahui bahwa alternatif $1 \& 2$ merupakan alternatif yang akan mengahsilkan value terbesar.

B. Saran

Saran yang dapat diberikan bagi perusahaan adalah:

1. Perusahaan harus mampu melakukan perbaikan sistem pencatatan pada berbagai aspek.

2. Proses perbaikan dilakukan secara continuous dengan dukungan dan komitmen berbagai pihak.

Sedangkan saran bagi penelitian selanjutnya adalah:

1. Perlu dilakukan lean assessment terhadap perusahaan terkait peningkatan kriteria perbaikan.

2. Penelitian selanjutnya dapat dilakukan dengan menghitung Net Present Value (NPV) dan Rate of Return (ROR) untuk mengetahui payback period terhadap investasi.

\section{DAFTAR PUSTAKA}

J. K. Liker and D. Meier, The Toyota Way. USA: Mc Graw Hill, 2006.

S. Wignjosoebroto, Ergonomi, Studi Gerak dan Waktu . Jakarta: Guna Widya, 1995.

M. SdRother and J. Shook, Learning to See, Value Stream Mapping to Create Value and Eliminate Muda. Cambridge: The Lean Enterprise Institute, Inc, 2003.

T. Ohno, Toyota Production System Beyond Large Scale Production. New York: CNC Press, 1988.

I. A. Rawabdeh, "A Model for The Assessment of Waste In Job Shop Environments," Int. J. Oper. Prod. Manag., pp. 800$822,2005$.

F. Chandler, "Using Root Cause Analysis to Understand Failures and Accident," Washington D.C., 2004.

C. Carlson, Understanding and Applying the Fundamentals of FMEAs. Arizona: ReliaSoft Corporation, 2014.

D. Dell'Isola, Quality Control, 2nd ed. Prentice Hall International Inc, 1986. 